\title{
Anticardiolipin antibodies in patients from Malaysia with systemic lupus erythematosus
}

\author{
H W Jones, R Ireland, G Senaldi, F Wang, M Khamashta, A J Bellingham, K Veerapan, \\ G R V Hughes, D Vergani
}

\begin{abstract}
Systemic lupus erythematosus (SLE) is highly prevalent in Malaysia, which has a mixed population of Malays, Chinese, and Indians. A quantitative enzyme linked immunosorbent assay (ELISA) was used to determine anticardiolipin antibody (aCL) levels (total immunoglobulin, IgG, and IgM) in 200 patients with SLE (164 Chinese, 26 Malay, and 10 Indian) attending the University Hospital of Kuala Lumpur, Malaysia, and 103 matched controls. Only $33(16.5 \%)$ of the patients had raised aCL levels; 26 had raised IgG aCL, five IgM aCL, and two both IgG and IgM aCL. There was a low prevalence of raised levels of aCL in the population studied, which was seen in conjunction with a rare occurrence of thrombosis. The classical association of high aCL levels with thrombocytopenia and recurrent abortions was noted, though not with cerebral disease. The low prevalence of aCL in this study population of mixed racial origin contrasts with findings in European patients with SLE and lends support to the influence of local factors, be they genetic or environmental, on the clinical manifestations of this disease.
\end{abstract}

Antibodies to cardiolipin (aCL) are part of a family of autoantibodies directed against cell membrane phospholipids. These antibodies have assumed importance in the past decade because their presence in some patients, especially those with systemic lupus erythematosus (SLE), has been associated with venous and arterial thrombosis, cerebral disease, recurrent fetal loss, and thrombocytopenia. ${ }^{1-4}$

In Malaysia SLE is common and found more often among the Chinese than the Indian or indigenous Malay populations. ${ }^{56}$ Thus ethnic factors seem to have an influence on the susceptibility to the disease.

We wondered whether levels of $\mathrm{aCL}$ are affected in patients with lupus from Malaysia by the ethnic or environmental background or reflect the clinical manifestations of the disease. Using a standardised enzyme linked immunosorbent assay (ELISA), ${ }^{78}$ we measured $\mathrm{aCL}$ levels in the sera of 200 ethnically distinct Malaysian patients with SLE attending a lupus outpatient clinic in Kuala Lumpur. Results were related to ethnic origins and clinical manifestations.

\section{Subjects and methods}

SUBJECTS

Serum samples were collected from 200 patients examined at the SLE outpatient clinic, University Hospital, Kuala Lumpur, Malaysia, by three of the authors (FW, KV, and RI). All patients fulfilled the revised American Rheumatism Association criteria for the classification of SLE. ${ }^{9}$ Of the 200 patients studied, 114 were assessed clinically at the time of serum collection and demographic details and prevailing clinical manifestations were recorded. The overall group included 176 women and 24 men, ranging in age from 12 to 66 years (mean age $31 \cdot 8$ ) and comprised 164 Chinese, 26 Malay, and 10 Indian.

One hundred and three healthy volunteers (93 female, 10 male, mean age 31.9 years; range 17-56; 74 were Chinese, 17 Malay, and 12 Indian) acted as controls. Coded serum samples from all subjects were stored at $-70^{\circ} \mathrm{C}$ until tested.

\section{MEASUREMENT OF aCL}

Measurements were carried out using a quantitative solid phase ELISA. ${ }^{7}$ Patient and control serum samples were first screened for aCL of all immunoglobulin isotypes with a peroxidase conjugated anti-IgG, IgA, and $\operatorname{Ig} M$ antiserum (Sigma, Poole, Dorset) to detect antibodies bound to solid phase cardiolipin (Sigma). Serum samples were then tested for aCL of the specific IgG and IgM isotypes with peroxidase labelled anti-IgG and IgM antisera (Sigma). The results were expressed in the units recommended by the aCL standardisation international workshop. ${ }^{8}$ A strongly positive sample was calibrated against affinity purified IgG aCL and IgM aCL standards and assigned values of $200 \mathrm{G}$ phospholipid (GPL) and $150 \mathrm{M}$ phospholipid (MPL) units respectively. Total immunoglobulin aCL values were assigned arbitary units using the GPL standard. Standard curves were prepared in each plate together with four known positive reference sera. Positive results were also graded as 'high', 'moderate', and 'low' as recommended in the above mentioned international workshop. ${ }^{8}$

\section{STATISTICAL ANALYSIS}

As the values of aCL followed a non-parametric distribution results were expressed as median and ranges and were compared by the use of the Wilcoxon's rank sum test. Correlations between age, disease duration, and $\mathrm{aCL}$ values were analysed by Spearman's rank regression analysis.

Statistical computations were performed using the statistical package for the social sciences (SPSS) on the University of London Computer Centre's Amdahl 5980/300. 
Table 1 Clinical manifestations in 114 patients from Malaysia with lupus. Results are given as number (\%) of patients

\begin{tabular}{lcccc}
\hline Manifestation & $\begin{array}{l}\text { Chinese } \\
(n=94)\end{array}$ & $\begin{array}{l}\text { Malay } \\
(n=15)\end{array}$ & $\begin{array}{l}\text { Indian } \\
(n=5)\end{array}$ & $\begin{array}{l}\text { Total } \\
(n=114)\end{array}$ \\
\hline Cutaneous & $90(96)$ & $15(100)$ & $5(100)$ & $110(96)$ \\
Articular & $88(94)$ & $15(100)$ & $5(100)$ & $108(95)$ \\
Renal & $65(69)$ & $12(80)$ & $4(80)$ & $81(71)$ \\
Haematological & $48(51)$ & $6(40)$ & $1(20)$ & $55(48)$ \\
Central nervous system & $36(38)$ & $4(27)$ & $2(40)$ & $42(37)$ \\
Pulmonary & $33(35)$ & $4(27)$ & $3(60)$ & $40(35)$ \\
Cardiac & $28(30)$ & $4(27)$ & $1(20)$ & $33(29)$ \\
Gastrointestinal & $24(26)$ & $3(20)$ & $2(40)$ & $29(25)$ \\
Sepsis & $24(26)$ & $3(20)$ & $1(20)$ & $28(25)$ \\
Thrombosis & $0(0)$ & $1(7)$ & $0(0)$ & $1(1)$ \\
\hline
\end{tabular}

\section{Results}

Full clinical details were obtained in 114 patients and are summarised in table 1. Articular, cutaneous, and renal manifestations were seen in most patients, being found in $95 \%, 96 \%$, and $71 \%$ respectively; no differences in the prevalence of the manifestations between the racial groups were noted. Only one patient had a history of thrombosis (deep vein thrombosis).

Levels of aCL were considered positive when they exceeded the highest control value, which was 12.0 units for total immunoglobulin $\mathrm{aCL}$, 7.5 GPL units for IgG aCL, and 5.0 MPL units for IgM aCL. Raised levels of aCL were found in $33 / 200(16.5 \%)$ of the patients with lupus. Twenty six (13\%) were IgG aCL positive, five $(2 \cdot 5 \%)$ were IgM aCL positive while two $(1 \cdot 0 \%)$ were positive for both isotypes. Values of total immunoglobulin and IgG aCL were significantly higher in patients than in controls (table 2), but similar between the ethnic groups. No 'high' positive levels of aCL were noted, but $9 / 28$ patients had 'moderate' levels of IgG aCL and 4/7 had 'moderate' levels of IgM aCL.

Total immunoglobulin aCL values were significantly correlated with age both in patients $(R=0.19, \quad p<0.05)$ and controls $(R=0.19$, $\mathrm{p}<0.05)$. Of the aCL isotypes, only IgG aCL levels correlated significantly with age, and only in the patient group $(R=0.14, p<0.05)$.

An inverse correlation was seen between total aCL levels and platelet count (table 3).

No differences were found in the prevalences of raised aCL between the three ethnic groups and no association was noted between aCL

Table 2 Median and ranges of anticardiolipin antibody $(a C L)$ values (units) in patients and controls

\begin{tabular}{lll}
\hline & $\begin{array}{l}\text { Total } \\
\text { immunoglobulin } a C L \\
\text { (arbitrary units) }\end{array}$ & $\begin{array}{l}\text { IgG } a C L \\
(G P L)\end{array}$ \\
\hline Controls & $4 \cdot 0(1-12 \cdot 0)$ & $2 \cdot 2(0 \cdot 3-7 \cdot 5)$ \\
Patients & $7 \cdot 0(2-131 \cdot 0)$ & $4 \cdot 0(0 \cdot 1-52 \cdot 0)$ \\
& $\mathrm{p}<0 \cdot 001$ & $\mathrm{p}<0 \cdot 001$ \\
\hline
\end{tabular}

Table 3 Correlation of peripheral blood platelet numbers with anticardiolipin antibody $(a C L)$ values

\begin{tabular}{|c|c|c|c|}
\hline & $\begin{array}{l}\text { Total } \\
\text { immunoglobulin } a C L\end{array}$ & $\underset{a C L}{I g G}$ & $\begin{array}{l}\operatorname{IgM} M \\
a C L\end{array}$ \\
\hline $\begin{array}{l}\text { Controls } \\
\mathbf{R} \\
\mathbf{p}\end{array}$ & $\begin{array}{l}0.012 \\
0.451\end{array}$ & $\begin{array}{l}0.064 \\
0.264\end{array}$ & $\begin{array}{l}0.086 \\
0.199\end{array}$ \\
\hline $\begin{array}{l}\text { Patients } \\
\mathbf{R} \\
\mathbf{p}\end{array}$ & $\begin{array}{r}-0.193 \\
0.024\end{array}$ & $\begin{array}{r}-0.142 \\
0.074\end{array}$ & $\begin{array}{r}-0.086 \\
0 \cdot 107\end{array}$ \\
\hline
\end{tabular}

$\mathbf{R}=$ Spearman's rank correlation coefficient. levels and specific organ disease, including renal and cerebral disease. The patient with a history of thrombosis did not have raised levels of aCL at the time of testing. Five women had a history of more than one abortion and two of these had the highest IgG aCL levels detected (50 and 31 GPL units). In addition, four of them had thrombocytopenia, though no thrombotic episodes.

\section{Discussion}

This study shows a singularly low prevalence of anticardiolipin antibody and the virtual absence of thrombosis in a large series of patients with lupus living in Malaysia. It outlines other clinical peculiarities of SLE in Malaysia and confirms the association of aCL with thrombocytopenia but not with cerebral disease.

In this study no differences in disease manifestations among patients belonging to different racial groups were noted. Of interest, however, is the observation that renal disease was present in over $70 \%$ of cases, a prevalence much higher than those reported in other series, which ranged from 19.6 to $50.0 \% .910$ This finding confirms a previous observation by Wang et $a l,{ }^{11}$ who noted that patients with lupus in Malaysia commonly have renal disease and a more severe form of membranous lupus nephritis than Western patients. In contrast with the prevalence of renal disease, thrombosis was extremely rare in our patients. This might be due to a bias in referral: thus patients with lupus presenting with thrombotic episodes might have been preferentially referred to nonSLE clinics. The clinical history of even our longstanding patients was consistently negative for thrombotic episodes, however, indicating that the low prevalence of thrombosis in our patients was genuinely an uncommon phenomenon.

It has been suggested that thrombotic manifestations in SLE are provoked by increased levels of antiphospholipid antibodies, especially $\mathrm{aCL}$ and 'lupus anticoagulant' antibody. ${ }^{2}$ of importance, therefore, is the observation that our patients had raised levels of aCL in their sera only occasionally, the antibody being present above normal in $16.5 \%$ of cases. This contrasts with findings in European patients with SLE, in whom the prevalence of aCL has been reported to vary from 39 to over $60 \%$. $^{12-15}$ The reason for this discrepancy is not known. Our patients had similar results despite their distinct ethnic origins, indicating that protection against thrombosis must be afforded by either genetic or environmental factors common to all three populations. Because our patients differ genetically we think that local factors, such as diet, are more likely to provide an explanation. High lipid intake is a known risk factor for thrombosis ${ }^{16}$ and may influence the production of aCL. If this hypothesis is correct, a low prevalence of raised $\mathrm{aCL}$ levels and thrombosis might be expected in patients with lupus living in South America and Asia, where the diet has a low fat content. ${ }^{16}$ Some support for this view comes from the studies by Saluja $e t$ $a l$ in India ${ }^{17}$ and by Chahade $e t$ al in Brazil. ${ }^{18}$ 
The first study showed that aCL was present in only $27 \%$ of Indian lupus patients, in whom thrombosis was also rare, and the second study found aCL in just $20 \%$ of cases in Brazil. Two further reports from South Africa show that although clinical characteristics of SLE in the black population do not differ from those described in series from other parts of the world, the prevalence of aCL is low. ${ }^{19} 20$ These findings further indicate that regional determinants, be they environmental or genetic, have an important role in governing aCL production.

In our series we did not find the reported correlation between aCL and cerebral disease, ${ }^{21}$ possibly because this complication results from levels of aCL higher than those found in our study. On the other hand, we confirmed that levels of aCL correlate positively with age $\mathrm{e}^{22-24}$ and negatively with the platelet count. ${ }^{325}$ The link between recurrent abortion and $\mathrm{aCL}^{3}$ was also supported by our findings as women with recurrent abortions had the highest levels of aCL.

Support for the notion that aCL causes disease is provided by two facts illustrated in this study. Firstly, the uniquely low occurrence of thrombosis in our patients with lupus was associated with the lowest prevalence of aCL yet reported in the disease. Secondly, the highest aCL levels were found in patients with thrombocytopenia. Moreover, it is becoming clear that autoantibodies are of two major immunoglobulin isotypes: IgG and IgM. ${ }^{26}$ Whereas IgM autoantibodies have low affinity, broad reactivity, and low damaging capacity, IgG autoantibodies have high affinity and specificity for their antigen and high damaging potential. ${ }^{26}$ In view of this the finding that aCL belongs predominantly to the IgG isotype may also be of pathogenic relevance.

In summary, the unexpected findings of absence of thrombosis and rarity of anticardiolipin antibodies in patients from Malaysia with lupus reinforce the association of the two and suggest an influence of regional factors on the manifestations of SLE.

Dr Ireland was supported by a grant from the Peel Medical Research Trust and a travelling fellowship from the British Society for Haematology. Dr Senaldi was a research fellow in the department of immunology of the King's College School of Medicine and Dentistry supported by the Royal Society, UK. Professor F Wang is supported by the CICHE, British Council, and a research and development grant from the University of Malaya. This work was supported by the British SLE AID group.

1 Hughes G R V. Autoantibodies in lupus and its variants: experience in 1000 patients. $\mathrm{Br}$ Med $\mathcal{F}$ 1984; 289: 339-42.

2 Harris E N, Gharavi A E, Hughes G R V. Anti-phospholipid antibodies. Clin Rheum Dis 1985; 11: 591-5.
3 Harris E N, Chan J K H, Asherson R A, et al. Thrombosis, recurrent fetal loss and thrombocytopenia: predictive value of the anticardiolipin antibody test. Arch Intern Med 1986; 146: $2153-6$.

4 Asherson R A, Harris E N. Anticardiolipin antibodiesclinical associations. Postgrad Med f 1986; 62: 1081-7.

5 Frank A O. Apparent predisposition to SLE in Chinese Frank A O. Apparent predisposition to SLE in Chinese
patients in West Malaysia. Ann Rheum Dis 1980; 39: patients
$266-71$.

6 Simmons P, Wang F, Adam B A, et al. Laboratory aspects of SLE in Malaysians. Asean fournal of Clinical Science 1982; 3: $323-7$

7 Gharavi A E, Harris E N, Asherson R A, Hughes G R V. Anticardiolipin antibodies: isotype distribution and phospholipid specificity. Ann Rhewm Dis 1987; 46: 1-6.

8 Harris E N, Gharavi A E, Patel S P, Hughes G R V. Evaluation of the anticardiolipin antibody test: report of an international workshop held 4 April 1986. Clin Exp Immunol 1987; 68: 215-22.

9 Tan E M, Cohen A S, Fries J F, et al. The 1982 revised criteria for the classification of SLE. Arthritis Rheum 1982; 25: 1271-7.

10 Ballou S P, Khan M A, Kushmer I. Clinical features of systemic lupus erythematosus. Arthritis Rheum 1982; 25 : $55-60$.

11 Wang F, Looi L M. Systemic lupus erythematosus with membranous lupus nephropathy in Malaysian patients. $Q \mathcal{F}$ Med 1984; 210: 209-15.

12 Biswas R M, Cronin M E, Bowerman D L, et al. A solid phase enzyme immunoassay (ELISA) for the detection and quantitation of anticardiolipin antibody. Am $\mathcal{J}$ Clin Pathol 1988; 90: 591-6.

13 Gharavi A E, Harris E N, Lockshin M D, Hughes G R V, Elkon K B. IgG subclass and light chain distribution of anticardiolipin and anti-DNA antibodies in systemic lupus erythematosus. Ann Rheum Dis 1988; 47: 286-90.

14 Harris E N, Gharavi A E, Boey M L, et al. Anti-cardiolipin antibodies: detection by radioimmunoassay and association with thrombosis in systemic lupus erythematosus. Lancet with thrombosis in

15 Meyer O, Piette J-C, Bourgeois P, et al. Anti-phospholipid antibodies: a disease marker in 25 patients with antinuclear antibody negative systemic lupus erythematosus (SLE). Comparison with a group of 91 patients with antinuclear antibody positive SLE. $f$ Rheumatol 1987; 14: 502-6.

16 Bierman E L. Atherosclerosis and other forms of arteriosclerosis. In: Braunwald E, Isselbacher K J, Petersdorf R G, Wilson J D, Martin J B, Fauci A S, eds. Harrison's principles of internal medicine. 11th ed. New York: McGrawHill, 1988: 1016-23.

17 Saluja S, Kuma A, Khamashta M, Hughes G R V, Malaviya A N. Anticardiolipin antibodies in patients with systemic lupus erythematosus (SLE) in India: prevalence and clinical associations. Indian $\mathcal{F}$ Med Res 1990; 92: 224-7.

18 Chahade W H, Staub H L, Khamashta M A, Hughes G R V. Antiphospholipid antibodies in a Brazilian population with Antiphospholipid antibodies in a Brazilian population with 446-7.

19 Dessein P H, Gledhill R F, Rossouw D S. Systemic lupus erythematosus in black South Africans. S Afr Med $\mathcal{F}$ 1988; 74: 387-9.

20 Dessein P H, Gledhill R F, Asherson R A. Anticardiolipin antibody negative occlusive vascular retinopathy in systemic lupus erythematosus. Ann Rheum Dis 1990; 49: 133-4.

21 Asherson R A, Khamashta M A, Gil A, et al. Cerebrovascula disease and antiphospholipid antibodies in systemic lupus erythematosus, lupus-like disease, and the primary antiphospholipid syndrome. Am $\mathcal{F}$ Med 1989; 86: 391-9.

22 Tomer Y, Shoenfeld Y. Ageing and autoantibodies. Autoimmunity 1988; 1 : 141-9.

23 Fields R A, Toubbeh $H$, Seares $R$ P, Bankhurst A D. The prevalence of anticardiolipin antibodies in a healthy elderly prevulation and its association with antinuclear antibodies. population and its association

24 Manoussakis M N, Tzioufas A G, Silis M P, Pange P J E Goudevenos J, Moutsopoulos H M. High prevalence of anticardiolipin and other autoantibodies in a healthy elderly population. Clin Exp Immunol 1987; 69: 557-65.

25 Khamashta M A, Harris E N, Gharavi A E, et al. Immune mediated mechanism for thrombosis; antiphospholipid antibody binding to platelet membranes. Ann Rheum Dis 1988 ; $47: 849-54$.

26 Casali P, Notkins A L. CD5 + B lymphocytes, polyreactive antibodies and the human B-cell repertoire. Immunology Today 1989; 10: 364-8. 